\title{
TINJAUAN BIAYA PENGGUNAAN ALAT BERAT PADA PROYEK PENGASPALAN JALAN UJONG PACU-COT TRIENG KECAMATAN MUARA SATU KOTA LHOKSEUMAWE
}

\author{
M. Fauzan ${ }^{1)}$, Mukhlis ${ }^{2}$, M. Danil ${ }^{3)}$ \\ Jurusan Teknik Sipil, Fakultas Teknik, Universitas Malikussaleh
}

\begin{abstract}
Abstrak
Perencanaan perancangan struktur jalan raya harus mempunyai nilai rancang yang kuat, stabil, dan aman mampu bertahan sampai usia yang direncanakan. Adapun peralatan yang dibutuhkan dalam pekerjaan pengaspalan tersebut adalah : Compressor, Asphalt sprayer, Dump Truck, Asphalt finisher, Tandem Roller, Tire Roller dan Asphalt Mixing Plant (AMP) itu sendiri. Maka dengan hal tersebut diatas penyusun mencoba menganalisis peralatan-peralatan yang digunakan untuk pekerjaan pengaspalan seperti analisis biaya alat per jam dari masing - masing alat, effisiensi waktu produktif alat dan menentukan jumlah dump truck yang optimum. Tinjauan Biaya Pengaspalan Jalan Ujoeng Pacu-Cot Trieng Kecamatan Muara Satu Kota Lhokseumawe, dengan panjang 3,5 km. Di analisis kembali dengan menggunakan metode Analisis Soedrajat, S.A (cara modern) (1994) hasilnya dibandingkan dengan perhitungan Kontraktor. Dari perhitungan penulis diperoleh biaya pekerjaan pengaspalan keseluruhan $\mathrm{Rp}$. 2.013.035.500,-. dengan harga $1 \mathrm{~m}^{2}$ Rp. 115.030,6,- yang terinci antara lain, biaya penggunaan tenaga kerja sebesar Rp. 8.785.000,- biaya penggunaan material sebesar Rp. 1.942.755.500,- biaya pengunaan peralatan sebesar Rp. 61.495.000,- sedangkan jumlah perhitungan kontraktor Rp. 2.021.468.949,dengan harga $1 \mathrm{~m}^{2}$ Rp. 115.512,51,- maka selisih perhitungan penilis dengan kontraktor yaitu Rp. 8.433.449,- dengan selisih harga $1 \mathrm{~m}^{2} \mathrm{Rp}$. 481,91,- sehingga biaya yang didapat penulis lebih kecil dari pada yang didapat oleh kontraktor. Hal tersebut dikarenakan oleh perbedaan penggunaan analisa yang dipakai oleh penulis dengan menggunakan metode modren Soedrajat (1994), sedangkat kontraktor menggunakan teknis (Direktorat Jendral Bina Marga Program Jalan Lokal Kabupaten, Kota Lhokseumawe).
\end{abstract}

Kata Kunci: Biaya, Waktu Pelaksanaan, Tenaga Kerja dan Peralatan.

\section{Pendahuluan}

Penggunaan alat berat biasanya diperuntukkan untuk proyek-proyek yang berskala besar yaitu bervolume tinggi dan dalam pengerjaannya tidak mungkin lagi dikerjakan oleh manusia. Untuk mendapatkan hasil pekerjaan yang memuaskan (tepat waktu dan ekonomis) dengan menggunakan alat berat sebagai alat bantu, perlu dilakukan perencanaan (penataan) secara teliti dan akurat untuk setiap waktu pekejaan sesuai dengan jenis proyek yang dikerjakan.

Dalam rangka pencapaian hasil ini, selalu diusahakan pelaksanaan pengawasan mutu, pengawasan waktu pelaksanaan, dan pengawasan penggunaan biaya. Ketiga kegiatan pengawasan ini harus dilaksanakan dalam waktu yang bersamaan. Pada setiap pekerjaan pembangunan yang cukup besar, pemakaian alat- alat berat hampir tidak dapat dihindarkan. Pemakaian alat-alat berat selain 
cepat selesai juga pada beberapa pekerjaannya lebih rapi. Tetapi tidak boleh dilupakan adalah biaya dari pekerjaan itu sendiri. Oleh karena itu pada pekerjaan ini penaksiran anggaran biaya adalah proses perhitungan volume pekerjaan, harga dari berbagai macam bahan dan peralatan pekerjaan yang akan dikerjakan pada pekerjaan pengaspalan Jalan Ujong Pacu - Cot Trieng Kecamatan Muara Satu Kota Lhokseumawe.

\section{Tinjauan Kepustakaan}

\subsection{Analisa Biaya Satuan}

Suatu rumusan ditentukan harga satuan menurut jenis pekerjaan yang tercantum indek analisis dan hasilnya dalam bentuk tabel pada setiap pekerjaan, yaitu analisa satuan ini terdiri dari: a. Biaya alat; b. Biaya operasi; c. Biaya kepemilikan; d. Biaya penyusutan

\subsection{Biaya Persatuan Produksi}

Menurut Rochmanhadi (1994), setelah menghitung biaya-biaya kepemilikan dan biaya-biaya operasi untuk tiap-tiap alat, kapasitas atau produksi tiap-tiap alat ataupun produksi armada alat, maka bisa menentukan biaya persatuan produksi, adalah sebagai berikut:

$$
\mathrm{BP}=\frac{\text { Biaya kepemilikan }+ \text { Biaya operasi alat } / \text { Armada alat }}{\text { Produksi alat } / \text { Armada alat }} \ldots
$$

\subsection{Waktu Siklus}

Menurut Rostiyanti F,S (2002), Siklus kerja dalam pemindahan material merupakan suatu kegiatan yang dilakukan berulang. Pekerjaan utama didalam kegiatan tersebut adalah menggali, memuat, memindahkan, membongkar muatan, dan kembali ke kegiatan awal. Semua kegiatan tersebut dapat dilakukan oleh satu alat atau oleh beberapa alat.

Waktu yang diperlukan didalam siklus kegiatan diatas disebut waktu siklus atau cycle time (CT). Waktu siklus terdiri dari beberapa unsur yaitu:

1. Waktu muat atau loading time (LT), merupakan waktu yang dibutuhkan oleh suatu alat untuk memuat material ke dalam alat angkut sesuai dengan kapasitas alat angkut tersebut.

2. Waktu angkut atau hauling time (HT), merupakan waktu yang diperlukan oleh suatu alat untuk bergerak dari tempat pemuatan ke tempat pembongkaran. Waktu angkut tergantung dari jarak angkut, kondisi jalan, tenaga alat, dan lain-lain.

3. Waktu kembali atau return time (RT), merupakan waktu alat kembali ketempat pemuatan. Waktu kembali lebih singkat dari pada waktu berangkat karena kendaraan dalam keadaan kosong.

4. Waktu pembongkaran atau dumping time (DT), merupakan unsur penting dari waktu siklus. Waktu ini tergantung dari jenis alat, dan metode yang dipakai.

5. Waktu tunggu atau spotting time (ST), pada saat alat kembali ketempat pemuatan adakalanya alat tersebut perlu antri dan menunggu sampai alat diisi kembali. Saat mengantri dan menunggu ini yang disebut waktu tunggu.

Tinjauan Biaya Penggunaan Alat Berat Pada Proyek Pengaspalan Jalan Ujong PacuCot Trieng Kecamatan Muara satu Kota Lhokseumawe - M Fauzan, Mukhlis, M Daniel 


\subsection{Perhitungan Produksi Alat}

Menurut Rochmanhadi (1994), dalam merencanakan proyek-proyek yang dikerjakan dengan alat-alat berat, satu hal yang sangat penting adalah bagaimana menghitung kapasitas oparasi alat berat. Peralatan yang digunakan pada pelaksanaan pengaspalan jalan ini adalah:

1. Comprersor

2. Asphalt Sprayer

3. Dump Truck

4. Asphalt Finisher

5. Tandem Roller

6. Pheneumatic Tired Roller

7. Water Tang Truck

8. Asphalt Mixing Plan (AMP)

\subsubsection{Compressor}

Compressor adalah alat yang digunakan untuk pekerjan membersihkan sampah-sampah atau debu-debu yang ada pada permukaan jalan yang akan diaspal. Menurut Soedrajat (1994), untuk mendapatkan produktifitas compressor digunakan rumus sebagai berikut:

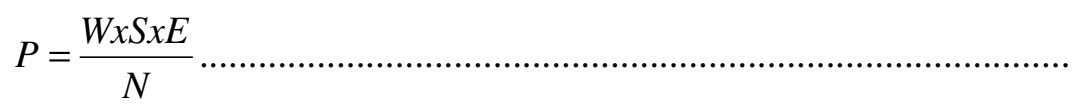

Keterangan :

$$
\begin{aligned}
& \mathrm{P}=\text { Produktifitas Kerja Compressor }\left(\mathrm{m}^{2} / \mathrm{jam}\right) \\
& \mathrm{W}=\operatorname{Lebar} \text { sapu putar }(\mathrm{m}) \\
& \mathrm{S}=\operatorname{Kecepatan} \text { rata-rata }(\mathrm{m} / \mathrm{jam}) \\
& \mathrm{E}=\text { Efesien kerja alat } \\
& \mathrm{N}=\text { Jumlah lintasan }
\end{aligned}
$$

\subsubsection{Asphalt Sprayer}

Jenis peralatan yang digunakan pada pekerjaan penyemprotan Asphalt cair (Primer coat tack coat) adalah Asphalt sprayer. Menurut Soedrajat (1994), untuk menghitung Asphalt spayer digunakan rumus sebgagai berikut:

$$
\mathrm{P}=\mathrm{W} \times \mathrm{S} \times \mathrm{E} \times \mathrm{p}
$$

Keterangan:

$$
\begin{aligned}
& \mathrm{P}=\text { Produktifitas Kerja Compressor }\left(\mathrm{m}^{3} / \mathrm{jom}\right) \\
& \mathrm{W}=\text { Lebar sapu putar }(\mathrm{m}) \\
& \mathrm{S}=\text { Kecepatan gerak alat }(\mathrm{m} / \mathrm{jam}) \\
& \mathrm{E}=\text { Efesien kerja alat } \\
& \mathrm{p}=\text { Tebal Lapis Perekat }(\mathrm{m})
\end{aligned}
$$

\subsubsection{Dump Truck}

Dump Truck berfungsi sebagai alat pengangkut Asphalt beton (Laston) dari tempat pengolahan Asphalt kelokasi pembuatan pekerjaan jalan, sering digunakan alat angkut khusus seperti : 
- Dump Truck kapasitas 5 ton

- Trailer kapasitas 35 ton

- Dumper kapasitas 20 ton

Menurut Soedrajat (1994), untuk menghitung Waktu siklus Dump Truck digunakan rumus :

$$
C m t=\frac{q D T}{q A F}+\frac{D}{V 1}+t 1 \frac{D}{V 2}+t 2
$$

Keterangan :

$$
\begin{array}{ll}
\mathrm{Cmt} & =\text { Waktu siklus Dump truck (menit) } \\
\mathrm{qDt} & =\text { Kapasitas Dump truck } \\
\mathrm{QAF} & =\text { Produktifitas Asphalt finisher }(\mathrm{m} / \text { menit }) \\
\mathrm{D} & =\text { Jarak angkut material }(\mathrm{m}) \\
\mathrm{V} 1 & =\text { Kecepatan dump truck bermuatan }(\mathrm{m} / \mathrm{menit}) \\
\mathrm{V} 2 & =\text { Kecepatan dump truck terkosong }(\mathrm{m} / \mathrm{menit}) \\
\mathrm{t} 1 & =\text { Waktu buang material } \\
\mathrm{t} 2 & =\text { Waktu Pengisian material }
\end{array}
$$

Untuk menghitung produktifitas dump truck digunakan rumus sebagai berikut:

$$
Q d t \frac{q \times 60 x E}{C m t}
$$

Keterangan :

$$
\begin{array}{ll}
\mathrm{qDT} & =\text { Produktifitas kerja dump truck (menit) } \\
\mathrm{q} & =\text { Produktifitas persiklus }\left(\mathrm{m}^{3}\right) \\
\mathrm{Cmt} & =\text { Waktu siklus dump truck } \\
\mathrm{E} & =\text { Efisiensi dump truck }
\end{array}
$$

Untuk menghitung banyaknya dump truck yang diperlukan digunakan Rumus:

$$
\mathrm{M}_{1} \frac{Q A F}{Q D T}
$$

Keterangan :

$\mathrm{M}_{1} \quad=$ Untuk banyaknya Dump truck diperlukan (unit)

QAF = Produktifitas Asphalt finisher (m/menit)

qDT = Produktifitas kerja dump truck (menit)

\subsubsection{Asphalt Finisher}

Asphalt Finisher adalah alat untuk penghamparan lapisan Laston yang dihamparkan pada permukaan badan jalan. Asphalt Finisher ini dilakukan setelah material diangkut oleh Dump Truck. Asphalt finisher terdapat alat seperti hopper (corong tuang) tetapi tidak mempunyai alas, sehingga material yang dituangkan oleh truck lagsung kebawah, dibagian belakangnya terdapat pisau selebar hopper (corong tuang) tersebut yang diatur sedemikian rupa, sehingga tingginya diatas jalan antara 0-14 cm (belum padat) menurut yang dinginkan. 
Menurut Soedrajat (1994), untuk menghitung produktifitas kerja Asphalt Finisher digunakan rumus sebagai berikut:

$$
\mathrm{QAF}=\mathrm{W} \times \mathrm{S} \times \mathrm{E} \times \mathrm{p}
$$

Keterangan :

$$
\begin{aligned}
\text { QAF } & =\text { Prodiktifitas Asphalt Finisher }\left(\mathrm{m}^{3} / \mathrm{jam}\right) \\
\mathrm{W} & =\text { Lebar alat spreader }(\mathrm{m}) \\
\mathrm{S} & =\text { Kecepatan gerakan alat }(\mathrm{km} / \mathrm{jam}) \\
\mathrm{E} & =\text { Efesien kerja alat } \\
\mathrm{p} & =\text { Tebal lapisan hamparan }
\end{aligned}
$$

\subsubsection{Tandem Roller}

Tanden Roller berfungsi sebagai alat pemadat awal untuk lapisan Asphalt Beton (Laston) yang dipadatkan pada suhu $90^{\circ} \mathrm{C}$ sampai dengan $110^{\circ} \mathrm{C}$. Tandem Roller ini bekerja setelah penghamparan Asphalt oleh Asphalt Finisher.

Menurut Soedrajat (1994), untuk menghitung produktifitas tandem roller digunakan rumus sebagai berikut :

$$
P=\frac{W x S x E}{N} x p
$$

Keterangan :

$$
\begin{aligned}
& \mathrm{P}=\text { Produktifitas kerja Tandem Roller }\left(\mathrm{m}^{3} / \mathrm{jam}\right) \\
& \mathrm{W}=\text { Lebar Roller }(\mathrm{m}) \\
& \mathrm{S}=\text { Kecepatan gerakan alat }(\mathrm{km} / \mathrm{jam}) \\
& \mathrm{N} \\
& \mathrm{p}
\end{aligned}
$$

\subsubsection{Pneumatic Tired Roller}

Pneumatic Tired Roller berfungsi sebagai alat pemadat terakhir pada saat penghamparan Asphalt Beton (Laston) yang dipadatkan pada suhu $80^{\circ} \mathrm{C}$. Menurut Soedrajat (1994), untuk menghitung produktifitas kerja Pneumatic Tired Roller digunakan rumus sebagai berikut :

$$
P=\frac{W x S x E}{N} x p
$$

Keterangan :

$$
\begin{array}{ll}
\mathrm{P} & =\text { Produktifitas kerja Tandem Roller }\left(\mathrm{m}^{3} / \mathrm{jam}\right) \\
\mathrm{W} & =\text { Lebar Roller }(\mathrm{m}) \\
\mathrm{S} & =\text { Kecepatan gerakan alat }(\mathrm{km} / \mathrm{jam}) \\
\mathrm{N} & =\text { Jumlah lintasan bolak balik } \\
\mathrm{P} & =\text { Tebal pemadatan }(\mathrm{m})
\end{array}
$$

\subsubsection{Water Tank Truck}

Water Tank Truck berfungsi sebagai alat untuk mengangkut air yang kemudian dimasukkan kedalam Tandem Roller dan Pnuematic Tired Roller pada 
saat pemadatan. Alat ini bekerja satelah pemadatan akhir yang dilakukan oleh Pnuematic Tired Roller. Menurut Soedrajat (1994), untuk menghitung produktifitas water tank truck dengan menggunakan rumus sebagai berikut :

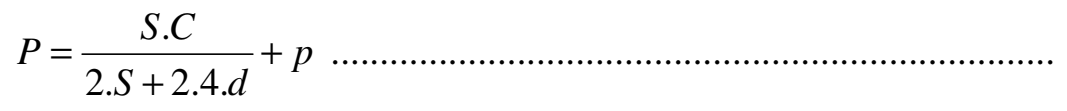

Keterangan:

$$
\begin{aligned}
& \mathrm{P}=\text { Produktifitas kerja alat }\left(\mathrm{m}^{3} / \mathrm{jam}\right) \\
& \mathrm{S}=\text { Kecepatan gerak alat }(\mathrm{km} / \mathrm{jam}) \\
& \mathrm{C}=\text { Kapasitas tangki }\left(\mathrm{m}^{3} \text { atau liter }\right) \\
& \mathrm{d}=\text { Jarak angkut }(\mathrm{km} \text { atau meter })
\end{aligned}
$$

\subsubsection{Asphalt Mixing Plan (AMP)}

Pemakaian aspal/butimen untuk keperluan jalan bisanya berupa campuaran antara aspal + agregat + filler (abu batu), dengan aturan tanpa bahan tambahan lainnya. Fungsi aspal/butimen ini secara umum dipakai untuk lapisan penutup. Proses pengolahan aspal atau hot mixed bituminous yang digunakan untuk kepentingan pembuatan pekerjaan jalan. Suhu aspal pada saat pencampuran $135^{\circ} \mathrm{C}$ dan agregatnya dipanaskan pada suhu $150^{\circ} \mathrm{C}$, kemudian tiga bahan ini dicampurkan menjadi satu, lalu diangkut ketempat pekerjaan dihamparkan, sewaktu aspal keadaan panas, lalu dipadatkan/digilas. Pada saat pemadatan suhu minimumnya $107^{\circ} \mathrm{C}$. dalam produksi aspal berkapasitas besar dilakukan dengan menggunakan sebuah plant (tempat pengolahan aspal). Dalam $1 \mathrm{~m}^{3}$ lapisan aspal beton (laston) : aspal 5,191 kg, filler (abu batu) 0,709 kg, agregat kasar 0,0176 $\mathrm{m}^{3}$ dan agregat halus $0,0182 \mathrm{~m}^{3}$.

\subsection{Tenaga Kerja}

Kebutuhan tenaga kerja pada pelaksanaan suatu proyek merupakan suatu hal yang sangat penting. Maka keadaan tenaga kerja dalam suatu pekerjaan harus benar-benar diperhatikan. Menurut Soedrajat (1994), kebutuhan tenaga kerja untuk suatu pekerjaan sangat tergantung dari jenis pekerjaan dan keadaan setempat serta ketrampilan dari pekerja itu sendiri. Dan biasa dipakai cara harian sebagai unit waktu dan banyaknya pekerjaan yang dapat diselesaikan dalam satu hari tapi akhir-akhir ini banyak dipergunakan cara yang lebih memuaskan yaitu dengan cara tiap jam kerja, karena panjang jam kerja dapat berlainan ada yang 6, $7,8,9$, sampai 10 jam per hari jadi sudah biasa sekarang upah dihitung per jam.

\subsection{Time Schedule (Rencana Kerja)}

Menurut Ibrahim Bachtiar (2001), Time schedule ialah waktu yang telah ditentukan. Jadi yang dimaksud dengan time schedule ialah, mengatur rencana kerja dari satu bagian atau unit pekerjaan. Time schedule meliputi kegiatan antara lain:

a. Kebutuhan tenaga kerja

b. Kebutuhan material

c. Kebutuhan waktu.

d. Dan kebutuhan transportasi/pengangkutan 
Dari time schedule/rencana kerja, kita akan mendapat gambaran lama pekerjaan dapat diselesaikan, serta bagian-bagian pekerjaan yang saling terkait antara satu dengan yang lain. Sebelum menyusun rencana kerja, harus diperhatikan bagian-bagian pekerjaan yang terkait satu sama lain, serta pekerjaan yang dapat dimulai tanpa menunggu pekerjaan yang lain selesai.

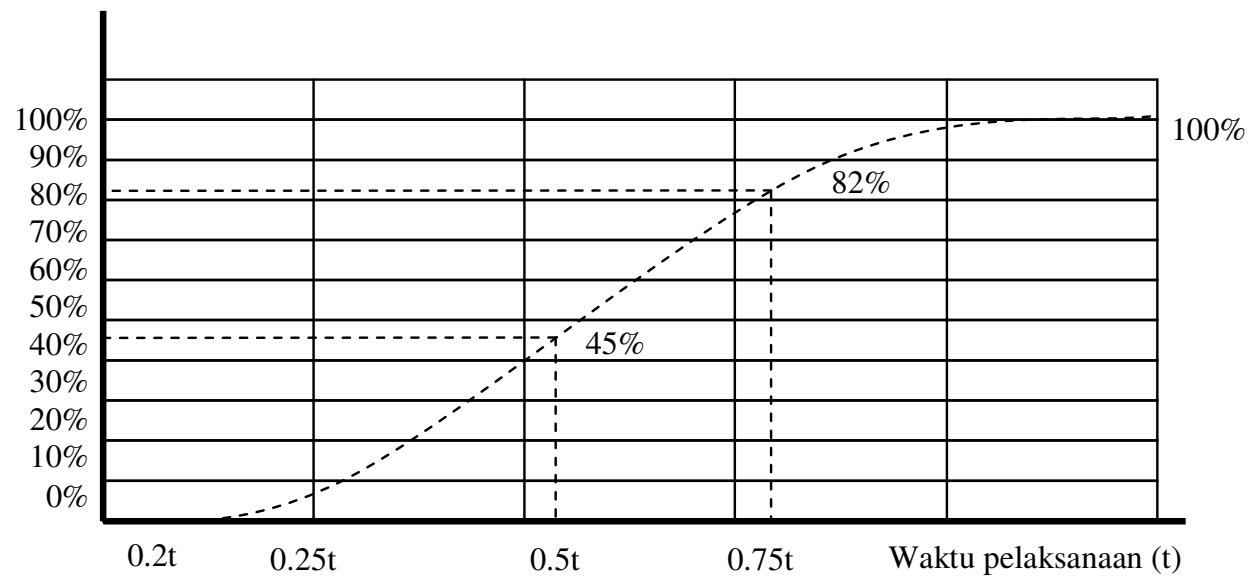

Gambar 1 Rencana Kerja (Time Schedule) Sumber: Djojowirono (2005)

\section{Metode Penelitian}

Penelitian ini dilaksanakan pada Proyek Pengaspalan Jalan Ujong Pacu - Cot Trieng Kecamatan Muara Satu Lhokseumawe Provinsi Aceh. Pengumpulan data dilakukan dengan survei lapangan dan mengumpulkan literatur-literatur yang berhubungan dengan penelitian. Pengumpulan data dilakukan dengan cara meminta data kontrak pekerjaan kepada kontraktor. Pengolahan data dilakukan dengan menggunakan persamaan-persamaan yang berhubungan dengan perhitungan produktifitas alat berat yang digunakan untuk proyek tersebut. Adapun analisa harga satuan yang digunakan untuk menghitung biaya proyek tersebut adalah dengan menggunakan metode Soedrajat (1994).

\section{Hasil dan Pembahasan}

\subsection{Penjadwalan Penggunaan Peralatan}

Pelaksanaan penggunaan peralatan pada setiap aktifitas harus memiliki urutan-urutan pekerjaan sesuai dengan pelaksanaan pekerjaan masing-masing. Urutan-urutan pekerjaan tersebut yaitu:

1. Pekerjaan pembersihan medan kerja yang merupakan pekerjaan awal sebelum dimulai.

2. Pekerjaan lapisan resap pengikat yaitu pekerjaan penyemprotan tack coat dengan menggunakan Asphalt Spayer. Pekerjaan ini dilakukan sebelum penghamparan lapis aspal beton (laston)

3. Pekerjaan pengangkutan lapis aspal beton (laston), yaitu pengangkutan material dari asphalt mixing plant (AMP) kelokasi dengan peralatan Dump Truck 
4. Pekerjaan penghamparan Laston, yang dilakukan dengan menggunakan peralatan Asphalt Finisher

5. Pekerjaan pemadatan dengan Tandem Roller, pekerjaan dilakukan sebanyak enam kali passing untuk tahap pertama.

6. Pekerjaan pemadatan dengan Pnuematic Tired Roller, pemadatan ini dilakukan setelah Tandem Roller menggilas.

\subsection{Penggunaan Biaya Tenaga Kerja}

Kebutuhan tenaga kerja dalam pelaksanaan tiap jenis pekerjaan diperhitungkan menurut kemampuan serta ketrampilannya. Hal ini ditentukan oleh lamanya jam kerja yang digunakan serta jumlah tenaga kerja yang dipakai, penggunaan tenaga kerja yang kurang memadai akan menghasilkan produktivitas yang lebih kecil. Efektivitas jam kerja dalam 1 (satu) hari dilaksanakan 7 jam, kebutuhan biaya tenaga kerja disesuaikan dengan pekerjaan yang dilaksanakan.

\subsection{Pekerjaan Lapisan Resap Pengikat (Prime Coat)}

Pekerjaan pembersihan debu dengan compressor. Kebutuhan biaya tenaga kerja untuk pekerjaan pembersihan dengan luas $17500 \mathrm{~m}^{2}$ dibutuhkan tenaga kerja 1 orang mandor, 1 orang operator terlatih, 1 orang pekerja terlatih dengan biaya sebesar Rp. 1.155.000,- Pada pekerja lapis resap pengikat dengan menggunakan Asphalt Sprayer. Kebutuhan biaya tenaga kerja untuk pekerja lapis resap pengikat dengan luas $17500 \mathrm{~m}^{2}$ dibutuhkan tenaga kerja 1 orang operator terlatih, 1 orang pekerja terlatih dan 1 orang pekerja tak terlatih dengan biaya sebesar Rp. $945.000,-$

\subsection{Pekerjaan Laston}

Pada pekerjaan menggunakan Dump Truck, Kebutuhan biaya tenaga kerja pengangkutan material Laston dengan volume $1050 \mathrm{~m}^{3}$ kebutuhan tenaga kerja 1 orang mandor, 4 orang sopir dan 4 orang pekerja tak terlatih dengan biaya sebesar Rp. 2.730.000,- Untuk Pekerjaan menggunakan Asphalt Finisher, Kebutuhan biaya tenaga kerja penghamparan Laston volume pekerjaan $1050 \mathrm{~m}^{3}$ dibutuhkan tenaga kerja 1 orang operator terlatih, 2 orang pekerja terlatih, dan 2 orang pekerja tak terlatih dengan biaya sebesar Rp. 1.540.000,- sementara pada Pekerjaan menggunakan Tandem Roller kebutuhan biaya tenaga kerja pemadatan awal Laston volume $1050 \mathrm{~m}^{3}$ dibutuhkan tenaga kerja 1 orang mandor, 1 orang operator terlatih, 2 orang pekerja terlatih dengan biaya sebesar Rp. 665.000,Pekerjaan menggunakan Pneumatic Tired Roller Kebutuhan biaya pemadatan akhir Laston dengan volume pekerjaan $1050 \mathrm{~m}^{3}$ dibutuhkan tenaga kerja 1 orang mandor, 1 orang operator terlatih, 2 pekerja terlatih dengan biaya sebesar Rp. 665.000,- Pada Pekerjaan menggunakan Water Tank Truck Kebutuhan biaya tenaga kerja untuk pekerjaan pengisian air kedalam Tandem Roller dan Pneumatic Tired Roller dengan volume $1050 \mathrm{~m}^{3}$ dengan kebutuhan biaya tenaga kerja 1 orang supir dan 1 orang pekerja tak terlatih dengan biaya sebesar Rp. 1.085.000,-

\subsection{Penggunaan Biaya Material}

Pada sebuah pelaksanaan proyek selalu memerlukan material pada tiap tahapan yang akan dikerjakan, material yang digunakan pada proyek peningkatan jalan ini adalah material yang terdiri dari Prime Coat dan Laston. 
Biaya material untuk Prime Coat dan lapisan Laston pada pekerjaan pengaspalan jalan Ujong Pacu-Cot Trieng Kecamatan Muara Satu Kota Lhokseumawe yaitu sebesar Rp. 38.944.500,-

\subsection{Penggunaan Biaya Peralatan}

Pada pelaksanaan sebuah proyek selalu memerlukan berbagai peralatan yang sangat tergantung pada tahapan pekerjaan yang akan dilaksanakan, peralatan yang digunakan harus disesuaikan dengan jenis pekerjaan serta besarnya volume pekerjaan yang akan dilaksanakan, kebutuhan biaya peralatan tergantung pada jenis pekerjaan yang akan dilaksanakan.

\subsubsection{Pekerjaan Pembersihan Dan Lapis Resap Pengikat}

Pekerjaan menggunakan Compressor untuk pembersihan dengan luas pekerjaan $17500 \mathrm{~m}^{2}$ dengan menggunakan 1 unit compressor, maka diperlukan biaya sebesar Rp. 9.800.000,- Pada pekerjaan menggunakan Asphal Sprayer untuk pekerjaan lapis resap pengikat dengan luas pekerjaan $17500 \mathrm{~m}^{2}$ dengan menggunakan 1 Unit Asphalt Sprayer. Maka diperlukan biaya sebesar Rp. 2.940.000,-

\subsubsection{Pekerjaan Laston (Lapis Asphalt Beton)}

Pekerjaan Menggunakan Dump Truck untuk pekerjaan pengangkutan material laston dengan volume pekerjaan $1050 \mathrm{~m}^{3}$ dengan menggunaka 4 Unit Dump Truck, maka diperlukan biaya sebesar Rp. 16.660.000,- Pada pekerjaan menggunakan Asphalt Finisher Untuk penghamparan lapis laston dengan volume pekerjaan $1050 \mathrm{~m}^{3}$ dengan menggunakan 1 unit Asphalt Finisher. Maka diperlukan biaya sebesar Rp. 10.780.000,- Pekerjaan Menggunakan Tandem Roller Untuk pekerjaan pemadatan awal pada lapisan laston dengan volume pekerjaan $1050 \mathrm{~m}^{3}$ dengan menggunakan 1 unit Tandem Roller. Maka diperlukan biaya sebesar Rp. 7.350.000,- Untuk pekerjaan Menggunakan Pneumatic Tired Roller pekerjaan pemadatan akhir pada lapisan laston dengan volume pekerjaan $1050 \mathrm{~m}^{3}$ dengan menggunakan 1 unit Pneumatic Tired Roller. Maka diperlukan biaya sebesar Rp. 9.800.000,- dan Pekerjaan menggunakan Water Tank Truck untuk pekerjaan pengisian air kedalam Tandem Roller dan Pneumatic Tired Roller dengan volume pekerjaan $1050 \mathrm{~m}^{3}$ dengan menggunakan 1 unit Water Tank Truck, maka diperlukan biaya sebesar Rp. 9.165.000,-

\subsection{Anggaran Biaya}

Anggaran biaya dalam satu proyek diperlukan dalam menerjemahkan biaya proyek tersebut, pada proyek peningkatan jalan ini diperlukan adanya suatu sistem cara perhitungan yang sesuai dan baik. Total Biaya Tenaga Kerja adalah sebesar Rp. 8.785.000,- dan total Biaya Material adalah Rp. 1.942.755.500,- sedangkan total biaya untuk peralatan adalah sebesar Rp. 53.900.000,- jadi total keseluruhan biaya adalah sebesar Rp. 2.005.440.500,-

\section{Kesimpulan dan Saran}

\subsection{Kesimpulan}

Berdasarkan analisa perhitungan, maka dapat diambil beberapa kesimpulan antara lain :

Tinjauan Biaya Penggunaan Alat Berat Pada Proyek Pengaspalan Jalan Ujong PacuCot Trieng Kecamatan Muara satu Kota Lhokseumawe - M Fauzan, Mukhlis, M Daniel 
1. Total biaya untuk pengaspalan jalan terdiri dari total biaya untuk tenaga kerja adalah sebesar Rp. 8.785.000,- dan total biaya untuk material adalah sebesar Rp. 1.942.755.500,- sedangkan total biaya untuk peralatan adalah sebesar Rp. 61.495.000,- jadi total keseluruhan biaya adalah sebesar Rp. 2.013.035.500,-.

2. Biaya pengaspalan sebesar Rp. 2.013.035.500,- sepanjang $3,5 \mathrm{~km}$ dengan harga dalam $1 \mathrm{~m}^{2}$ senilai Rp. 115.030,6,- dan waktu kerja efektifnya dalam 1 hari adalah 7 jam, sedangkan hasil perhitungan biaya pengaspalan jalan ini diperoleh oleh kontraktor adalah sebesar Rp. 2.021.468.949,- sepanjang 3,5 $\mathrm{km}$ dengan harga dalam $1 \mathrm{~m}^{2}$ senilai Rp. 115.512,51,-.

3. Biaya berdasarkan hasil penelitian lebih kecil dari pada perhitungan kontraktor. Hal tersebut dikarenakan oleh perbedaan penggunaan analisa, yaitu penulis menggunakan analisa metode Modern Soedrajat (1994) dan Rochmanhadi (1983), sedangkan kontraktor menggunakan analisa Teknis Direktorat Jendral Bina Marga.

\subsection{Saran} berikut :

Berdasarkan dari hasil penelitian diatas dapat diberikan saran-saran sebagai

1. Sebaiknya untuk menghitung suatu biaya penggunaan alat berat digunakan Metode Soedrajat (1994) untuk menghemat biaya konstrukai.

2. Salah satu cara untuk menghemat biaya konstruksi adalah dengan mengerjakan pekerjaan proyek selesai tepat waktu.

\section{Daftar Kepustakaan}

Bagian Pengadaan 2009, Analisis Harga Satuan Pekerjaan Tertinggi, Setdakab Aceh Utara Tahun 2009

Harley Toni. 1991. Aplikasi Alat-Alat Besar. Technical Consulting Departemen PT. United Tractor.

Rochmanhadi, 1994, Perhitungan Biaya Pelaksanaan dengan Menggunakan Alat-alat Berat, Badan Penerbit Departemen Pekerjaan Umum Penerbit Departemen Pekerjaan Umum

Rostiyanti Fatena, S., 2002. Alat Berat Untuk Proyek Konstruksi, Penerbit PT Rineka Cipta, Jakarta.

Soedrajat S.A, 1994. Analisa (Cara Modern) Anggaran Biaya Pelaksanaan, Penerbit Nova, Bandung.

Soeharto, Iman. 1995. Menajemen Proyek, Penerbit Erlangga Jakarta. 